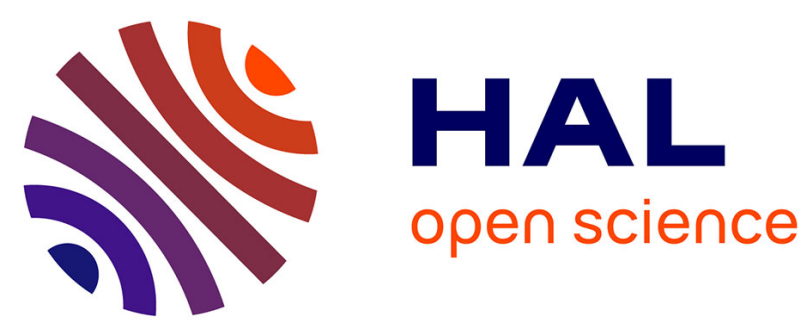

\title{
MECHANICAL PROPERTIES OF ZIRCONIA TOUGHENED ALUMINA PREPARED BY DIFFERENT METHODS
}

P. Homerin, F. Thevenot, G. Orange, Gilbert Fantozzi, V. Vandeneede, Anne Leriche, F. Cambier

\section{To cite this version:}

P. Homerin, F. Thevenot, G. Orange, Gilbert Fantozzi, V. Vandeneede, et al.. MECHANICAL PROPERTIES OF ZIRCONIA TOUGHENED ALUMINA PREPARED BY DIFFERENT METHODS. Journal de Physique Colloques, 1986, 47 (C1), pp.C1-717-C1-721. 10.1051/jphyscol:19861108 . jpa00225503

\section{HAL Id: jpa-00225503 https://hal.science/jpa-00225503}

Submitted on 1 Jan 1986

HAL is a multi-disciplinary open access archive for the deposit and dissemination of scientific research documents, whether they are published or not. The documents may come from teaching and research institutions in France or abroad, or from public or private research centers.
L'archive ouverte pluridisciplinaire HAL, est destinée au dépôt et à la diffusion de documents scientifiques de niveau recherche, publiés ou non, émanant des établissements d'enseignement et de recherche français ou étrangers, des laboratoires publics ou privés. 
JOURNAL DE PHYSIQUE

Colloque $\mathrm{C1}$, supplément au $\mathrm{n}^{\circ} 2$, Tome 47 , février 1986 page c1-717

\title{
MECHANICAL PROPERTIES OF ZIRCONIA TOUGHENED ALUMINA PREPARED BY DIFFERENT METHODS
}

\author{
P. HOMERIN, F. THEVENOT, G. ORANGE+ , G. FANTOZZI; \\ V. VANDENEEDE* ${ }^{*}$ A. LERICHE* and F. CAMBIER* \\ C.R.R.A.C.S., E.N.S.M.S.E., 158, Cours Fauriel, \\ F-42023 Saint-Etienne Cedex 2, France \\ + INSA, Bât. 502, 20, Avenue Albert Einstein, \\ F-69621 Villeurbanne Cedex, France \\ "C.R.I.B.C., 4, Avenue Gouverneur Cornez, B-7000 Mons, Belgium
}

\begin{abstract}
Résumé - Des céramiques alumineuses renforcêes par de la zircone ont été préparēes par deux procédés différents à partir des mêmes matières premières (poudres). Le premier utilise le broyage par attrition et la compression à chaud ; le second, une dispersion électrochimique, le coulage en barbotine et le frittage sans charge. L'influence des paramètres d'èlaboration sur les propriētés mécaniques des pièces denses est examinée. L'influence des teneurs en $\mathrm{ZrO}_{2}$ et $\mathrm{Y}_{2} \mathrm{O}_{3}$ est discutée.

Abstract - Zirconia Toughened Alumina (ZTA) ceramics were prepared by two different methods from the same raw materials (powders). The first one using attrition miliing and hot-pressing; the second, electrochemical dispersion, slip casting and pressureless sintering. The influence of the processing parameters on the mechanical properties of dense material is examined. The influence of $\mathrm{ZrO}_{2}$ and $\mathrm{Y}_{2} \mathrm{O}_{3}$ contents is discussed.
\end{abstract}

I - INTRODUCTION

The fracture toughness enhancement of ceramics using phase transformation of zirconia was originally devoted to Partially Stabilized Zirconia (PSZ) $/ 1,2 \%$. It was recently extended to composite systems made of zirconia particles dispersed in a matrix of another phase (Zirconia Toughened Ceramics : ZTC) /2,3/. Zirconia Toughened Alumina (ZTA) $/ 4,5 /$ seems to be of growing interest because of the promising resuits which have been reported and because of its potential development. However, previous works show that significant strengthening can be achieved only by optimized dispersion of the second phase and a close control of the zirconia particles size which must be maintained lower than the critical transformation size $\left(d_{R C}\right) / 6$ / (1. e. less than 1 to a few micrometers according to the nature and amount of zirconia high temperature phase stabilizer e.g. yttria). This aim can be achieved either by homogenizing techniques, i.a. fine grinding and mixing (attrition milling) or 
by wet chemical techniques (sol-gel or electrochemical repulsion methods) $/ 3 /$. Microcracking, stress-induced transformation toughening and compressive surface stresses $17,8,9 /$ are the most often invoked mechanisms; they are based on the tetragonal to monoclinic transformation of zirconia $/ 10 /$.

II - EXPERIMENTAL METHODS

II-1 - Preparation methods

II-1-I - Mechanical homogenizing

Four compositions were chosen for this study: $\mathrm{Al}_{2} \mathrm{O}_{3}, \mathrm{Al}_{2} \mathrm{O}_{3}-10,15$ and 45 vol $\% \mathrm{ZrO}_{2}$ $\left(+3 \mathrm{~mol} \% \mathrm{Y}_{2} \mathrm{O}_{3}\right)$. The composite powders were prepared for sintering by mixing $\mathrm{Al}_{2} \mathrm{O}_{3}\left({ }^{1}\right), \mathrm{ZrO}_{2}\left({ }^{2}\right)$ and $\mathrm{Y}_{2} \mathrm{O}_{3}\left({ }^{3}\right)$ by attrition milling in water (zirconia balls and plastic vesse1) in order to reduce the particles size. The grinding time varied from 2.25 to 18 hours. Polyvinyl alcohol (PVA) was added as a binder to the suspensions which were spray-dried. The resulting agglomerated powders were compacted by unidirectionnal pressing (400 MPa). The pellets were "debonded" and hot-pressed (30 $\mathrm{MPa}$ in graphite dies) at $1500^{\circ} \mathrm{C}$ for $15 \mathrm{~min}$ under vacuum.

\section{II-1-2 - Electrochemical repulsion}

Three different siurries (alumina $\left({ }^{1} 4\right.$, zirconia $\left({ }^{2}\right)$ and yttria $\left({ }^{3}\right)$ ) were prepared separately. The nature of the suspensions ( $\mathrm{pH}$, surfactants, dry product contents..) was chosen from electrokinetical potential $\zeta$ and sedigraphic as well as rheological (viscosity ...) measurements. The three slurries were mixed together in the required weight fractions in order to obtain the desired compositions : 0 to $15 \mathrm{vol} \% \mathrm{ZrO}_{2}$ $\left(+1\right.$ or $\left.3 \mathrm{~mol} \% \mathrm{~V}_{2} \mathrm{O}_{3}\right)$. Then they were vibro energy milled (alumina cylinders, plastic bottle) and slip cast in plaster molds. The green products were dried for several days and pressureless sintered in air at $1550^{\circ} \mathrm{C}$ for 2 hours.

\section{II-2 - Characterization methods}

The ratio of tetragonal to monoclinic zirconia was determined by X-Ray Diffraction (XRD, Cu K $\mathrm{K}_{\alpha}, 25 \mathrm{~mA}, 40 \mathrm{KV}$ ) on as-sintered surfaces according to the Porter and Heuer's relation /11/.

The dense bodies were machined into bars $\left(18 \times 4 \times 3 \mathrm{~mm}^{3}\right)$ which were polished (SiC and diamond grit). The fracture strength $\left(\sigma_{F}\right)$ and fracture toughness $\left(K_{I C}\right)$ measurements were carried out in a 3 point bend test with a span width of $15 \mathrm{~mm}$. For $\mathrm{K}_{\mathrm{Ic}}$ values determination, a notch (length about $1.6 \mathrm{~mm}(a / w \simeq 0.4)$ and tip radius about $80 \mu \mathrm{m})$ was introduced with a low speed diamond saw.

( $\left.{ }^{2}\right)$ RC172DBM, The Reynolds Company, USA

$\left({ }^{2}\right)$ UPH"V", CRICERAM, $F$ 
III - RESULTS AND DISCUSSION

\section{III-1 - Results obtained by mechanical dispersion}

Figure 1 presents the effect of attrition milling on $\sigma_{F}$ for a composite $\mathrm{Al}_{2} \mathrm{O}_{3}-15$ vol $\% \mathrm{ZrO}_{2}\left(+3 \mathrm{~mol} \% \mathrm{Y}_{2} \mathrm{O}_{3}\right)$. The increase of $\sigma_{\mathrm{F}}$ with the grinding time can be correlated to the reduction of the critical defect size as well as the size of both matrix and zirconia particles. The optimum is reached for an attrition milling time of about 9 hours. The $K_{I C}$ values of this composite (containing oniy tetragonal

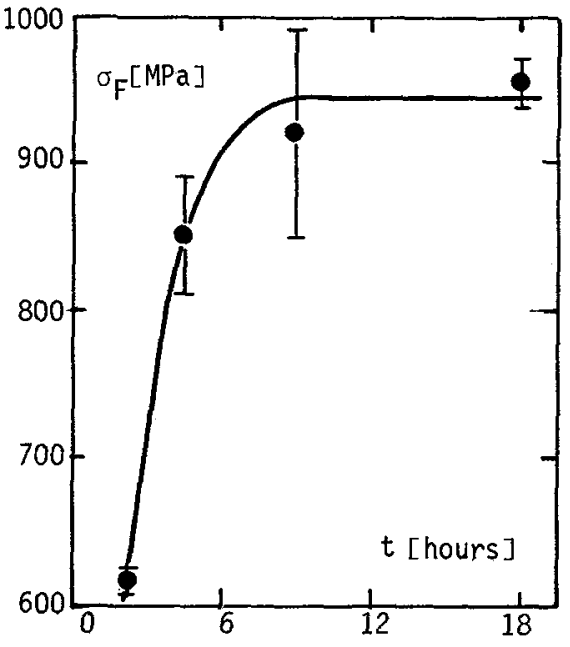

Fig. 1 - Strength of ZTA ( 15 vol $\% \mathrm{ZrO}_{2}$ $\left(+3 \mathrm{~mol} \% \mathrm{Y}_{2} \mathrm{O}_{3}\right)$ ) versus attrition milling time.

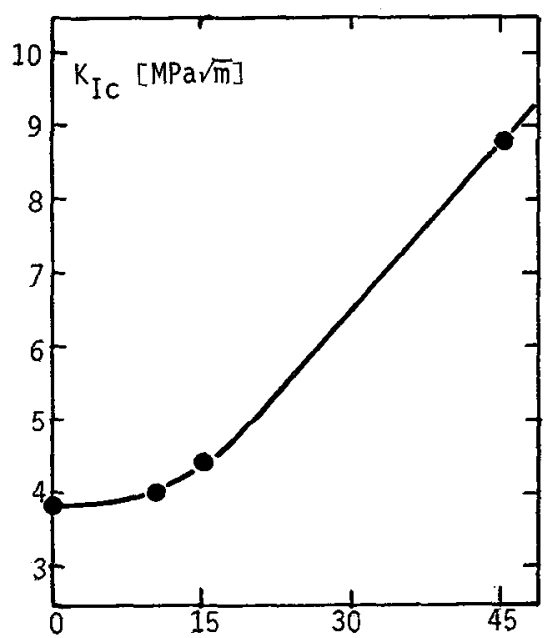

vol $\% \mathrm{ZrO}_{2}\left(3 \mathrm{~mol} \% \mathrm{Y}_{2} \mathrm{O}_{3}\right)$

FIG. 2 - Toughness of ZTA versus yttria-zirconia content for a given attrition milling time ( 4.5 hours).

zirconia particles) are only slightly higher than the $\mathrm{Al}_{2} \mathrm{O}_{3}$ matrix toughness and are not affected by grinding (even up to 18 hours). In fact, the density and size of particles are not high enough for effective transformation toughening $\left(d<d_{U C}\right)$ 16/. For higher zirconia contents, one can observe an important enhancement of $K_{I C}$ (figure 2). Up to 15 vol $\% \mathrm{ZrO}_{2}\left(+3 \mathrm{~mol} \% \mathrm{Y}_{2} \mathrm{O}_{3}\right)$, there is nearly no transformation toughening; with increasing volume fraction up to $45 \mathrm{vol} \% \mathrm{ZrO}_{2}$ (+3 $\mathrm{mol} \%$ $\mathrm{Y}_{2} \mathrm{O}_{3}$ ), the density and size of transformable particles increase and the contribution of stress-induced transformation toughening becomes more and more effective. The $K_{I c}$ values increase from $3.9\left(\mathrm{Al}_{2} \mathrm{O}_{3}\right.$ matrix toughness) to $8.7 \mathrm{MPa} \sqrt{\mathrm{m}}$ (composite with 45 vol $\% \mathrm{ZrO}_{2}\left(+3 \mathrm{~mol} \% \mathrm{Y}_{2} \mathrm{O}_{3}\right)$ ) and the $\sigma_{\mathrm{F}}$ from 660 to $1200 \mathrm{MPa}$. The simultaneous increase of both $\sigma_{F}$ and $K_{I c}$ with the yttria-zirconia volume fraction is consistent with a stress-induced phase transformation toughening mechanism. This assumption is confirmed by XRD which does not reveal monoclinic zirconia in any composite. 
III- 2 - Results obtained by electrochemical dispersion

The $K_{I c}$ values of slip cast and pressureless sintered ZTA versus yttria-zirconia addition are plotted (figure 3 ) for two yttria contents : 1 and 3 mol $\%$

The wide spread of fracture strength values, which is the consequence of the presence of important defects (pores) due to slip casting, does not allow one to detect any significant evolution. However samples (composition : $\mathrm{Al}_{2} \mathrm{O}_{3}-15$ vol \% $\mathrm{ZrO}_{2}$ $\left(+3 \mathrm{~mol} \% \mathrm{Y}_{2} \mathrm{O}_{3}\right)$ ) present a high $\sigma_{\mathrm{F}}(700 \mathrm{MPa})$ compared to the strength of slip cast $\mathrm{AT}_{2} \mathrm{O}_{3}$ (about $400 \mathrm{MPa}$ ).

For the highest stabilizer content $\left(3 \mathrm{~mol} \% \mathrm{Y}_{2} \mathrm{O}_{3}\right), \mathrm{K}_{\mathrm{Ic}}$ increases with the addition of zirconia which is essentially tetragonal (XRD, table 1). This means that the composite toughness enhancement is associated to the increasing of transformable phase volume as observed in the materials prepared by the previous method (mechanical dispersion followed by hot-pressing). Thus, here again, transformation toughening is the main reinforcement mechanism.

\begin{tabular}{|c|c|c|c|}
\hline Compositions & $\begin{array}{c}D \\
\left(\mathrm{~g} / \mathrm{cm}^{3}\right)\end{array}$ & $\begin{array}{r}P_{0} \\
(\%)\end{array}$ & $Q$ \\
\hline $\mathrm{Al}_{2} \mathrm{O}_{3}$ & 3.89 & 0.2 & --- \\
\hline $\mathrm{A}_{2} \mathrm{O}_{3}-10$ vol $\% \mathrm{ZrO}_{2}\left(+1 \mathrm{~mol} \% \mathrm{Y}_{2} \mathrm{O}_{3}\right)$ & 3.90 & 0.4 & 0.82 \\
\hline $\mathrm{Al}_{2} \mathrm{O}_{3}-15$ vol $\% \mathrm{ZrO}_{2}\left(+1 \mathrm{~mol} \% \mathrm{Y}_{2} \mathrm{O}_{3}\right)$ & 4.10 & 0.2 & 0.64 \\
\hline $\mathrm{AT}_{2} \mathrm{O}_{3}-10$ vol $\% \mathrm{ZrO}_{2}\left(+3 \mathrm{~mol} \% \mathrm{Y}_{2} \mathrm{O}_{3}\right)$ & 3.98 & 0.0 & 0.95 \\
\hline $\mathrm{Al}_{2} \mathrm{O}_{3}-15$ vol $\% \mathrm{ZrO}_{2}\left(+3 \mathrm{~mol} \% \mathrm{Y}_{2} \mathrm{O}_{3}\right)$ & 4.07 & 0.2 & 0.96 \\
\hline
\end{tabular}

Table 1 - Density (D), open porosity $\left(P_{0}\right)$ and tetragonal relative volume fraction of zirconia (Q) of some ZTA.

For the lowest yttria ( $1 \mathrm{~mol} \%$ ) content, the critical stress intensity factor shows substantial increase as a function of $\mathrm{ZrO}_{2}$, reaching a maximum at 10 vol $\% \mathrm{ZrO}_{2}$ addition ( $K_{I C}=5.8 \mathrm{MPa} \sqrt{\mathrm{m}}$ ). XRD analysis (table 1 ) revealed both monoclinic and tetragonal phases of zirconia. In this case, we have to take into account microcracking as a toughening effect, probably accompagnied by transformation toughening. The decrease of $K_{I c}$ after the maximum is explained by linking of microcracks between the $\mathrm{ZrO}_{2}$ particles resulting in macrocrack formation.

For given microstructure and second phase content, different stabilizer additions to zirconia do not affect grain size (d) itself but the critical sizes (d $d_{U C}$ and $d_{R C}$ ) and lead to specific mechanisms (microcracking and/or transformation toughening). 


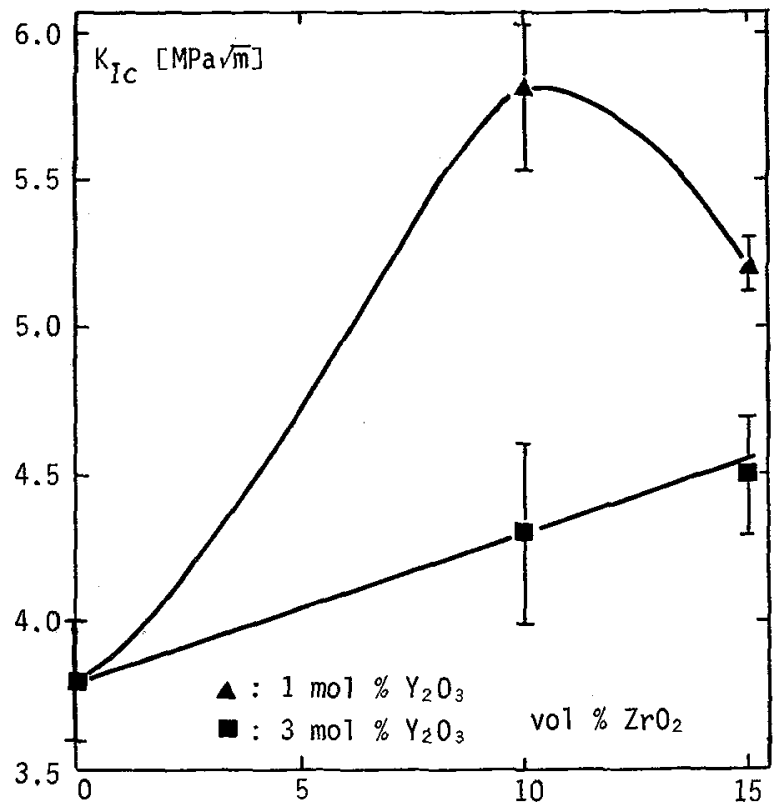

Fig. 3 - Toughness of ZTA versus yttriazirconia contents ( 1 and 3 mol \% $\mathrm{Y}_{2} \mathrm{O}_{3}$ additions in $\mathrm{ZrO}_{2}$ ).

IV - CONCLUSTONS

The results indicate that toughening of alumina can be utilized in various ways to enhance strength and/or toughness according to the compositions and processings. Further improvements will be possible by using a preparation method associating chemical and mechanical dispersions, cold shaping and sinter-hipping.

\section{ACKNOWLEDGMENT}

The authors acknowledge the European Community for its financial support.

\section{REFERENCES}

/1/ Garvie, R.C., Hannink, R.H.J., Pascoe, R.T., Nature 258 (1975) 703.

/2/ Science and technology of zirconia I, Cleveland, USA (1980); II, Stuttgart, Germany (1983).

13/ Claussen, N., Proc. Europ. Co 11. on Ceramics in Advanced Energy Technology, Petten, The Netherlands (Sep. 1982).

/4/ Claussen, N., J. Am. Ceram. Soc. 59 (1976) 49.

15/ Becher, P.F., J. Am. Ceram. Soc. 64 (1981) 37.

16/ Claussen, N., Petzow, G., Energy and Ceramics, Ed. P. Vincenzini (1980)680.

17/ Evans, A.G., Science and technology of zirconia II, Adv. in ceram. 12 (1984) 193, Ed. N. Claussen et a1., The Am. Ceram. Soc.

/8/ Lange, F.F., J. Mat. Sc. 17 (1982) 225.

/9/ Green, D.J., J. Mat. Sc. 19 (1984) 2165.

/10/ Wolten, G.M., J. Am. Ceram. Soc. 46 (1963) 418.

/11/ Porter, D.L., Heuer, A.H., J. Am. Ceram. Soc. 62 (1979) 298. 